\section{THE SIGNIFICANCE OF PUCCHA-VISSAJJANA IN THE BUDDHIST LITERATURE ${ }^{1}$}

\section{Pisit Kobbun $^{2}$}

\begin{abstract}
The use of pucchā-vissajjanā, question and answer, in the Pāli suttas reflects its significance as a literary technique for communicating the teachings of the Buddha. Pucchā-vissajjanā is a technique for teaching the dhamma employed by the Buddha and his disciples. It is a mnemonic technique for conveying and maintaining the teachings in the oral tradition and was kept as a written record until it becomes a tradition technique in composing postTipitaka Buddhist literature. When regarding the suttas as a textbook, the use of pucchā-vissajjanā in the suttas is important for the study of dhamma-vinaya. Constructing the suttas according to the pucchā-vissajjanā technique is favorable for dhamma practice and concentrationdevelopment. The pucchā-vissajjanā process is well in accord with the process of concentration-development for developing wisdom. As a result of this, those who study the suttas (the story being developed through
\end{abstract}

1 This paper is an excerpt from my dissertation entitled "Pucchā-vissajjanā: A Literary Technique in Buddhist Thai Literature" supported by The Thailand Research Fund (TRF) and The Graduate School of Chulalongkorn University. I am grateful to my supervisor Associate Professor Dr. Suchitra Chongstitvatana, and to Dr. Rupert Gethin for their valuable suggestion and comments.

${ }^{2}$ Ph.D. candidate in Thai, Department of Thai, Faculty of Arts, Chulalongkorn University, Bangkok, Thailand pucchā-vissajjanā) will thereby certainly be practicing concentration while studying the text.

\section{Introduction}

Pucchā-vissajjanā, question-and-answer, is a literary technique of questioning or bringing forward a dhamma issue for discussion $;^{3}$ this technique is a systematic process of questioning and answering. ${ }^{4}$ The answer to the question, or discussion of the issue, will come in the form of a clear, well-ordered, comprehensive analytical explanation. Pucchā-vissajjanā is an old tradition found in the Tipitaka. When the Buddha wanted to discuss a dhamma issue with his followers, he usually began with a question as a preamble; at other times, his disciples would discuss some issue and then go to ask the Buddha for the right answer.

Pucchā-vissajjanā is a technique of proposing and explaining philosophical and religious ideas. In the Indian tradition a dialogue of question-and-answer for doing away with doubt can be seen ubiquitously and philosophical debate is for the purpose of convincing the interlocutor to believe in what the opposite side believes and making the inquirer become a pupil of the one who is able to answer. This makes question-andanswer dialogues a literary form well known for the purpose of conveying teachings concerning religious and philosophical concepts. ${ }^{5}$ Dialogic inquiring pursues

\footnotetext{
${ }^{3}$ Thomas O. Sloane, Encyclopedia of Rhetoric (Oxford, 2001), p.654.

${ }^{4}$ Rhys Davids and William Stede (eds.), The Pāli Text Society's Pāli-English Dictionary (Oxford, 1998), p.463.

${ }^{5}$ Rabindra Nath Basu, A Critical Study of the Milindapañhā (Calcutta, 1978), p.2.
} 
knowledge and ideas, attempting to make comprehensible what is known and to convey knowledge to someone who has not yet understood. Moreover, Pucchāvissajjanā is a literary technique for constructing a system of thinking. To have clear thoughts and understanding, posing a thought or setting up the main point of the idea with scope is important because in so doing one sets up a process for explaining in a language that is appropriate for explaining that idea. Pucchā-vissajjanā has been held to be one "tradition" for development of narrative and conveying dhamma that has been maintained from the early Buddhist period until the present.

In this paper I consider the significance of pucchā-vissajjanā in 3 aspects.

Pucchā-vissajjanā as a teaching technique employed by the Buddha and his disciples.

Pucchā-vissajjanā as a method for maintaining and transmitting Buddhism.

Pucchā-vissajjanā as a literary technique that is favorable to concentrationdevelopment.

\section{Pucchā-vissajjnā as a teaching technique employed by the Buddha and his disciples}

It could be said that the era of the Buddha was an age of searching for wisdom, filled with philosophers in search of ways to end suffering according to their own conception. This led to wide debate on the matter of knowledge and the correct way to end suffering. ${ }^{6}$ One can say that this

\footnotetext{
${ }^{6}$ Shridhar B. Shrotri, The Doctrine of the Upanisads and Early Buddhism (Delhi, 1991), p.190.
}

was an age of growth and alertness in wisdom. Many questions regarding life and the highest goal of life emerged during these times. Buddhist teachings contradicted teachings of the sects that already existed and were in discord with many of the popular social customs and practices at that time. Thus, in the Tipitaka, the Buddha has to instruct other followers of other teachers with different. There is controversy regarding concepts and beliefs in many suttas such as Ambatta Sutta in which the Buddha discusses with ambattamanava which class (vanna) is higher, the Brahman or the khattiya. The Buddha answers that anyone who clings to birth status, family line, selfhood, avāha, vivāha, is certainly far from having excellent wisdom and conduct. Only when one can lay aside birth status, family line, selfhood, avāha, vivāha, can one attain excellent wisdom and conduct. ${ }^{7}$ This kind of argument about concepts and beliefs leads to knowledge that blossoms correctly. Those who cannot argue back with reasons lose and sometimes surrender themselves, becoming pupils, accepting and understanding that knowledge. The Buddha can make a follower from a different sect who believes in wrong teaching accept his way.

With evidence from the suttas, the Buddha uses the technique of pucchā-vissajjanā in debating and teaching dhamma. ${ }^{8} \mathrm{He}$

${ }^{7}$ Ambatta Sutta, in Maurice Walshe (trans.), Thus Have I Heard: The Long Discourses of the Buddha (London, 1987), pp.111-124.

8 For Example, Māghandiya Sutta, in I.B. Horner (tran), The collection of the Middle Length Saying (Mhj. vol.II), pp.181-192 pucchā-vissajjanā between the Buddha and māghandiya about the self-controlled of sense- 
employs this technique in order to do away with misunderstanding, to convince people to see the truth and establish right knowledge. It is a procedure of teaching that is rational and gradual.

At the time of the Buddha, a large number of people asked the Buddha and his disciples questions with a variety of intentions. Many of these questioners were genuinely interested in the truth of life. They asked out of curiosity and were looking for points to attack. Therefore, the ability to give the right answers, answers that are to the point, and suitable to the nature, motive, and wisdom of the inquirer is of great importance. A bhikkhu must study the appropriate manner of answering. The Buddha instructed a bhikkhu who was going to teach dhamma to go to Sāriputta to learn the appropriate way to answer questions. In the Pañhāpucchā Sutta Säriputta describes the characteristics of pucchā-vissajjanā, saying that there are 5 reasons for asking questions.

The venerable Säriputta said: 'all who question another are in five states (of mind) or one of them. What five? One being foolish and blind questions another; One filled with evil desires and covetousness; One contemptuously; One seeking knowledge; or one questions another uncertainly, thinking;

If questioned by me he explains rightly, it is well; but if questioned by me he explains incorrectly, I will explain to him.

faculties; Cülasaccaka Sutta (Mhj. Vol.I), pp. 280-290. - pucchā-vissajjanā between the Buddha and Aggivessana about the three characteristics (tilakkhana).
Reverend sir, all who question another are in these five states or in one of them.

Reverend sir, when I question another, verily I am thus minded: If I question another and he explains rightly, it is well; if not, I will rightly explain it to him. ${ }^{9}$

There are 4 ways to answer questions: 1) a categorical reply 2) replying by counterquestion and 3) discriminating reply and 4) the question which requires to be waived

One who is considered wise in answering is one who can choose the way of answering that is suited to the person and circumstance. We can see that in the suttas there are often people who come to ask questions of the Buddha and his disciples for various reasons. The Buddha and his disciples employ various means of answering: both those that are derived from cases in which the Buddha is the one who begins posing questions and cases in which someone comes to ask the Buddha questions.

The following example of the pucchāvissajjanā from the Sakkapañhā Sutta shows the systematic method and process for presenting the teaching:

Q. By what fetters are they boundgods, humans, asuras, nagas, gandhabbas, and whatever other great classes of being

\footnotetext{
${ }^{9}$ Pañhāpucchā Sutta, E.M. Hare (trans.), The Book of the Gradual Sayings. Vol.III (London, 1973), p.141.

${ }^{10}$ Pañhāpayākarana Sutta, F.L. Woodward (trans.), The Book of the Gradual Sayings. Vol.II (London, 1982), pp.53-54.
} 
there be - in that they, wishing thus "Would that, without hatred, injury, enmity, or malignity, we might live in amity!" - do nevertheless live in enmity, hating, injuring, hostile, malign?

A. $\quad$ By the fetter of envy and selfishness are there bound-gods, men there be

Q. Envy and selfishness, what is the source thereof, the cause thereof? What give birth of them? How do they come to be? What being present, are envy and selfishness also present? What being absent, are they also absent?

A. Things dear and not dear to us this is source and cause of envy and selfishness, this is what gives birth to them, this is how they come to be. In the presence of what is dear or not dear, envy and selfishness come about, and in the absence of such feeling, they do not come about.

Q. What is the source, what the cause of things being dear or not dear, what gives birth of these feelings, how do they come to be? What being present, do we so feel, and what being absent, do we not so feel?

A. Desire is the source and cause of things being dear or not dear, this is what gives birth to such feelings, this is how they come to be. If desire being present, things become dear or not dear to us; if it be absent, things are no more felt as such.

Q. Desire, what is the source and cause of that, what gives birth to it, how does it come to be? What being present, is desire present, and what being absent, is desire also absent?

A. Mental pre-occupation this is the source, this is the cause of desire, this is what gives birth to desire, this is how desire come to be. Where is our mind preoccupied, for that desire arises; if our mind is not so pre-occupied, desire is absent.

Q. What is the source and what is the cause of mind being pre-occupied? What gives birth to such a state, how does it come to be? What being present, does our mind become pre-occupied, and what being absent, does it not?

A. The source, the cause of our becoming pre-occupied is what we may call obsession, this is what gives birth to preoccupation of mind, this is how that comes about. If that obsession is present, our mind is pre-occupied, if it is absent, it is not. ${ }^{11}$

The first five questions and answers in this sutta are ordered according to what is the source and what is the cause of things. How does it come to be? These questions and answers are presented in cause-effect relation of. Then, the form of pucchāvissajjanā changes to 'how' questions. And in answering, the Buddha classifies and gives more detailed information, as below:

Q. How has that bhikkhu gone about who has reached the path suitable for and leading to the cessation of obsession?

A. Happiness, Sorrow, Equanimity, I declare to be two-fold, according as it is to be followed after, or avoided. And the distinction I have affirmed in happiness, was drawn on these grounds:- When in following after happiness I have perceived that bad qualities developed and good qualities were diminished, then that kind of happiness was to be avoided. And when,

11 Sakkapañhā Sutta, T.W. and C.A.F. Rhys Davids (trans.), Dialogues of the Buddha (London, 1971), pp.310-312. 
following after happiness, I have perceived that bad qualities developed, then such happiness as is accompanied by pre-occupation and travail of mind, and of such as is not so accompanied, the latter is the more excellent. ${ }^{12}$

The Buddha explains the two-fold nature of happiness, sorrow and equanimity which is a system of explanation respectively.

Q. How has that bhikkhu gone about who has acquired the self-restraint enjoined by the Pātimōkkha?

A. I say that behavior in act and in speech, as well as those things we seek after are twofold, according as they are to be followed after or avoided. ${ }^{13}$

The Buddha, then, explains behavior in act, in speech and those things we seek after, respectively.

Q. How has that bhikkhu gone about who has acquired control of his faculties?

A. I say that the objects of the senses - visible, audible, odorous, sapid, tangible and mental objects - are twofold, according as they are to be followed after or avoided. ${ }^{14}$

He explains each of senses-visible, audible, odorous, sapid, tangible and mentalrespectively. After this the form of the questions and answers changes to 'yes-no' questions.

\footnotetext{
12 Ibid, pp.133-134.

13 Ibid, p.135.

${ }^{14}$ Ibid, p. 135.
}

Q. $\quad$ Are all recluses and Brahmins wholly of one creed, one practice, one persuasion, one aim?

A. No, they are not.

Q. Why are they not?

A. Of many and divers element is this world composed. And that being so, people naturally incline to adhere to one or another of those elements: and to whichever it be they, being so inclined, become strongly and tenaciously addicted, holding that "just this is true, the rest is foolish." And therefore it is that recluses and Brahmins are not all wholly of one creed, one persuasion, one aim. ${ }^{15}$

The next question is "Are all recluses and Brahmins perfectly proficient, perfectly saved, living the best life? Have they attained the right ideal?" The Buddha gives Indra an explanation. Eventually, Indra declares his delight at reaching clear teaching and he pays respect to the Buddha, who eliminates his doubts.

The pucchā-vissajjanā process is a teaching procedure. A point which has a clear scope is stated. In each sutta the teaching is on one issue or issues that are specifically connected, and involve participation, or interaction between the teacher and the pupil. The Buddha begins his teaching with an easy topic and goes onto more difficult and profound topics. The explanation progresses sequentially. The result is that the pupil can see and understand such knowledge. The aims and functions of pucchā-vissajjanā in the suttas can be summed up as follows:

\footnotetext{
${ }^{15}$ Ibid, p. 136.
} 
A technique for setting up a point of debate.

A technique for stating a point of dhamma.

A technique for developing ideas systemically and rationally.

A technique for provoking thought and analysis.

A technique for teaching and gradually educating.

A technique for converting and building faith.

\section{Pucchā-vissajjanā as a method for maintaining and transmitting Buddhism}

The study and transmission of Buddhist teachings during the early period occurred in the form of the oral tradition. Study was conducted through reciting Buddhist teachings. ${ }^{16}$ A point that is worth considering is that this method of learning through oral tradition not only allows a close relationship between pupil and teacher, but also helps in building meditative power in the pupil as it is practiced.

In this paper I will present the pucchāvissajjanā as a mnemonic technique and/or mnemonic function for maintaining and transmitting Buddhist teachings. A

${ }^{16}$ See. K.R. Norman, The Pāli Language and Scriptures (U.K, 1989), pp.29-34.; L.S. Cousins, Pāli Oral Literature (London, 1983), p.1.; Mark Allon, Style and Function: A Study of the Dominant Stylistic Features of the Prose Portions of Pali Canonical Sutta Texts and their Mnemonic Function (Tokyo, 1997), p.1. mnemonic function, as Mark Allon defines, it is an aid to memory, assisting in the learning and recall of memorized text. ${ }^{17}$

The council of dhamma-vinaya came into existence during the Buddha's life, as is evinced in the Sangitti Sutta. The Bhikkhus are worried that after the Buddha's death the dhamma-vinaya will be confused, as happened in the case of NiganthaNätaputta, in which there was division among disciples because of disagreement about the teachings. The Buddha suggested that there should be a council, whose members would memorize his teachings. This shows that even the Buddha was anxious about this matter and realized that his teachings should be collected and categorized for study, memorization, and the propagation of the Buddhist faith. Sāriputta suggested collecting dhamma-vinaya by sorting dhamma into points, beginning with section 1 to section 10, and explaining each section respectively. Sāriputta favored the systematic method of gathering and grouping dhamma-vinaya, the details of which are shown in the Sangīti sutta.

What is this one thing?

All beings are maintained by nutriment.

All beings are maintained by conditions.

There are (sets of) two things that were perfectly proclaimed by the Lord... Which are they?

Mind and body.

17 Mark Allon, The Oral Composition and Transmission of Early Buddhist Texts (London, 1997), p.43. 
Ignorance and craving for existence.

Belief in (continued) existence and belief in non-existence.

Lack of moral shame and lack of moral dread. ${ }^{18}$

This sutta consists of mnemonic lists given in groups in ascending numerical order from one to ten; significantly it is attributed not to the Buddha but to Säriputta. It can be viewed as a mnemonic summary of the contents of the Nikayas. ${ }^{19}$

In the Dasuttara Sutta, pucchā-vissajjanā is developed groups of dhammas from one to ten. The groups of dhammas are posed riddles. For example:

One thing that greatly helps.

One thing to be developed.

One thing to be thoroughly known.

One thing to be abandoned.

One thing that conduces to diminution.

One thing that conduces to distinction.

One thing hard to penetrate.

One thing to be made to arise.

One thing to be thoroughly learnt.

One thing to be realized.

\footnotetext{
${ }^{18}$ Sangīti Sutta, Thus Have I Heard, p.481.
}

${ }^{19}$ L.A.Cousins, pp.3-4.
Rhetorical questions are explained in numerical order. Sāriputta poses the questions and answers by himself as below:

Which one thing that greatly helps?

Tirelessness in wholesome states.

Which one thing to be developed?

Mindfulness with regard to the body, accompanied by pleasure.

Which one thing to be thoroughly known?

Contact as condition of the corruptions and grasping.

Which one thing to be abandoned?

Ego-conceit.

Which one thing that conduces to diminution?

Unwise attention.

Which one thing that conduces to distinction?

Wise attention.

Which one thing hard to penetrate?

Uninterrupted mental concentration.

Which one thing to be made to arise?

Unshakable knowledge.

Which one thing to be thoroughly learnt?

All beings are maintained by nutriment.

Which one thing to be realized?

Unshakable deliverance of mind.

That makes ten things that are real and true, so and not otherwise, unerringly and perfectly realized by the Tathägata. ${ }^{20}$

20 Dasuttara Sutta, Thus Have I Heard, pp. 511-512. 
Then, the Säriputta explains the dhamma in ten groups of two (making twenty points), ten groups of three (making thirty points), progressing up to ten groups of ten (amounting to one hundred points).

The council after the Buddhas' death was important in beginning to collect the dhamma-vinaya. In the first council, the pucchā-vissajjanā process was used for collection, categorization, and doublechecking. The Vinaya Pitaka mentions the origin of the council of dhamma-vinaya, in which Kassapa was the president. In the council, Kassapa played the role of the inquirer asking for the discipline (vinaya) from Upāli and asking for the suttas from Ananda. ${ }^{21}$ It is interesting that pucchāvissajjanā has been employed as an important device for memorizing the Buddha's teachings, because in the first three councils there were no written records. ${ }^{22}$ Thus, this shows the significance of pucchā-vissajjanā as the mnemonic standard or technique for transmitting the Buddha's teachings.

In the second council, Revata was in charge of inquiring. Sabbakāmī was in charge of answering. What is interesting about the second council as recorded is that it indicates the most appropriate conduct for the monks who perform the council's tasks. They must hold on to dhamma, vinaya,

21 Vinaya Pitaka, I.B. Horner (trans.), The Book of the Discipline. Vol. II (Oxford, 1938), pp.307-35; and described in Sangitiyavamsa, in Wannakam Samai Ratanakosin vol. 4 (Bangkok, 1996), pp.16-29.

22 See Rupert Gethin, 1992; K.R. Norman, 1989. and mātika ${ }^{2} \cdot{ }^{23}$ It can be noticed that there is the mātika category in addition here. This $m \bar{a} t i k \bar{a}$ is what would be developed into the Abhidhammapitaka during the third council. Mātikā means a 'matrix' or list of topics, a set of notes giving just the headings of a body of doctrine. ${ }^{24}$ The pucchā-vissajjanā came to have more importance in the $m \bar{a} t i k \bar{a}$ process as a technique for communicating dhamma by setting up a point prior to explication and sometimes they were riddle. This technique may not involve those who ask and answer, but it works in the way that one person both asks and answers, and this is the technique that appears in the Abhidhammapitaka. Moreover in the third council Moggaliputtatissa, the president, composed the Kathāvattu and incorporated it into the Tipitaka. We could infer from the style of the Kathāvattu that it was composed by setting up a "mātikā", which is the technique of the second council.

I believe mātika has a relationship to pucchā-vissajjanā since both are mnemonic techniques for studying and transmitting dhamma. As Rupert Gethin mentions, $m \bar{a} t i k \bar{a}$ is 'representing a technique of oral composition' ${ }^{25}$ and 'the list and subsequent mātika aids memorization of the dhamma not only by enabling one to conveniently sum up vast amounts of teaching, but also by helping one to find one's way around it; they provided a map of dhamma. ${ }^{26}$

How is pucchā-vissajjanā used as a mnemonic technique? The Pucchā-

\footnotetext{
${ }^{23}$ Vinaya-Pitaka, Vol. II.

${ }^{24}$ A.K. Warder, Indian Buddhism (Delhi, 1970), p.10.

25 Rupert Gethin, The Mātikā: Memorization, Mindfulness, and the List (New York, 1992), p.164.

${ }^{26}$ Ibid, p. 167.
} 
vissajjanā process is like the mātikā because pucchā is used to list issues for discussion or explanation. One who is a learned man and understands Buddhism profoundly just remembers questions (or sets of question), which are easy to answer. Therefore, pucchā serves as an aid to remember and arrange the dhamma in the oral tradition.

In the pucchā-vissajjanā process we can see techniques for helping the memorization and preservation of Buddhist teaching such as repetitive sentences, versification, and the arrangement of works according to length, all methods that had been used in India for centuries for the oral preservation of the Vada. ${ }^{27}$

The Written Tipitaka, I think, does not differ greatly from the oral tradition. That is, it is a written record produced from recitation, and the important thing is that keeping written records must be carried out strictly, with no error for any letter or any word. The sutta must be kept as a written record in order to serve as evidence of the continuation of the Buddhist teachings. There are clear statements on the correct procedure of recitation and record keeping. These must be performed strictly, since in reciting each word, writing down each word correctly, each word, each letter is tantamount to one image of the Buddha. ${ }^{28}$ In the Sangitiyavamsa can be seen the profit of reciting and keeping detailed records. Such notions are of great importance to the continuation of Buddhism.

\footnotetext{
${ }^{27}$ Donald S. Lopez, Jr., The Story of Buddhism: A Concise Guide to its History and Teachings (New York: 2001), p.106.

${ }^{28}$ Sangītiyavamsa, p.299.
}

An example of Buddhist literature that maintains and preserves the teachings and tradition of composing using the pucchāvissajjanā technique for development of narrative can be seen in the Milindapañhā. This allows one to see the interaction between the main characters, King Milinda and Nàgasena. Pucchā-vissajjanā in the Milindapañha $\bar{a}$ has both direct interrogation and analysis of the conflict in dhamma or buddhavacana. These are interesting literary techniques in the search for the right knowledge. In answering questions, Buddhist doctrines are explained through the use of imagery that is detailed, ingenious, and clear. The brilliance of both the content and form of the Milindapañh $\bar{a}$ makes this literary work widely known throughout the Buddhist world.

In Pucchā-vissajjanā there is organization, order, eloquence and refinement in the presentation. Since the teachings may be complicated and difficult, they need to be simplified and seen as distinct both for ease in memorizing and reading as a text.

\section{Pucchā-vissajjanā as a literary technique that is favorable to the ways of concentration-development}

The aims of Buddhist literature are to teach dhamma doctrines, give knowledge and illuminate understanding of Buddadhamma. Through a literary approach, it is possible to give clarity to the message for the understanding of Buddhist teachings, and also to bring about faith and pleasure in dhamma. Therefore, it is very important that in these aims the authors of Buddhist literature realize the relation between form and content, which must be combined harmoniously. It has been concluded earlier that pucchā-vissajjanā is a literary technique or paradigm that can display 
dhamma with unity and in accordance with the core of Buddhist ideas.

The pucchā-vissajjanā is a process that can convey dhamma powerfully and in a distinctly ordered manner, and consequently it is a literary tradition that has been retained since the earliest Buddhist era. Richard Gombrich has written that "the dhamma is the product of argument and debate, the debate going on in the oral culture of renouncers." ${ }^{29}$ Therefore, it would be interesting to examine further what may be other aspects in which pucchā-vissajjanā is significant. In this respect, the pucchāvissajjanā technique is favorable for concentration-development. ${ }^{30}$

In studying Buddhism, the capability of understanding clearly rests mainly on practice. Only through practice can the learner gain insights into Buddhist truth. However, the important basis of dhamma practice also depends on the basic knowledge gained through studying the texts. Understanding Buddhism through reading the text/scripture will lead to the right course of practice. In this respect, reading texts is also one way of dhamma practice. Here the aim is to discuss dhamma practice in the sense of concentration-development, which can be broadly defined as steadfastness of mind. Focusing and bringing the mind to bear upon one thing, it is a process by which awareness is narrowed down from its usual wide spectrum to a specific single point. ${ }^{31}$

29 Richard Gombrich, How Buddhism Began (Malaysia, 1994), p.13.

30 In this paper concentration-development means of practicing, training to develop or bring about Samādhi.

31 Paul Griffiths, Concentration or Insight: the Problematic of Theravada Buddhist Meditation-
The main concept of concentrationdevelopment is "to contemplate" one thing by keeping the mind focused and letting it move along and remain aware. It is the state in which the mind is placid in one temper.

There are many kinds of concentrationdevelopment, such as walking meditation, chanting and focusing upon the breathing that is a concentration in mind for focusing on anything by considering and seeing. All these methods of concentration development require focusing, and meditating steadfastly and repeatedly.

The process of concentration development needs to have objects of contemplation as suggested in texts like the Satipatthāna Sutta. Establishing Mindfulness ${ }^{32}$ is the method of seeing things as they are, watching the body, feeling, thought, and ideas. The Visuddhimagga (the path of purification) ${ }^{33}$ also mentions forty "paths to concentration", to be chosen according to each person's disposition. The principal concepts of all these methods of practicing concentration rest on "watching" "contemplating" and "repetitive practice".

Reading can also be considered as a way of concentration development, because reading involves the function of the mind. After it has been made clear that reading and the text are instruments for training concentration, what will now be examined is the method of composition that will help reinforce reading as a way of training concentration more

Theory, in the Journal of the American Academy of Religion, XLIX/4, p.606.

${ }^{32}$ Satipatthāna Sutta, Thus Have I Heard: The Long Discourses of the Buddha.

33 Buddhaghosa, Visuddhimagga (Kandy Sri Lanka, 1975) 
effectively. Developing this ability to repeatedly apply the mind leads to stability and ease.

Literary texts composed with pucchāvissajjanā can be compared to the human body, which is made up of different organs. These organs are all related, and relate to human activities. Therefore, concentrationdevelopment in watching the body is in congruence with texts composed by pucchā-vissajjanā, the structure of which is made up of different problems, which are all related. In the presentation of Buddhist knowledge on any subject, every member of the question-and-answer must be separately meditated upon, over and over again, in detail, until one becomes proficient. Then all of the questions and answers are synthesized into whole knowledge. Therefore pucchā-vissajjanā, which is gradual instruction presented in a step by step manner, in order to thoroughly purge one's temperament level by level from simple to difficult can contribute to concentration.

This systematic process of concentrationdevelopment with a steadfast mind that meditates on one thing is a way of thinking possibly related to the process of thinking know as yonisomanasikāra - systematic attention, analytical reflection, proper consideration. ${ }^{34}$ This constitutes a wise, thorough and realistic consideration of natural conditions; it entails finding issues of doubt, comparing obvious dhamma conditions to other natural conditions that are unclear, employing a firm mind that is not distracted.

\footnotetext{
${ }^{34}$ Pra Dhammapitaka, Dictionary of Buddhism (พจนานุกรมพุทธศาสตร์ ฉบับประมวลธรรม), p.400.
}

When considering the suttas, it can be seen that an important aspect of the pucchā-vissajjanā technique is its use as an instrument in concentration-development. It is a technique that is in harmony with the concentrationdevelopment method. Certainly the pucchāvissajjanā method is favorable for practicing concentration. It is a technique for considering doubts in order to do away with them. Therefore I think this technique can contribute to concentration development because:

Pucchā-vissajjanā is a technique for conveying dhamma pertaining to one specific subject. The reader is provided with a full scope of thoughts from the issue or dhamma problem that is raised. Therefore, his mind will set about focusing on one specific problem. Furthermore, beginning with a question is like inviting the individual to ruminate upon the subject.

Pucchā-vissajjanā is a process for conveying dhamma step by step. That is, gradually presenting knowledge, aiming for sequential consideration, one step at a time, one problem at a time. However, each problem is categorized by the type of relation, and is connected in the pucchā-vissajjanā structure in the form of consequences or cause-andeffect. The mind of the reader will gradually proceed, consider problems in sequence, and gradually come to understand the message, making connection to each problem; finally the practitioners come to understand the overall knowledge, which is the thought process, the process of considering each part in order to understand the overall meaning.

Pucchā-vissajjanā is the process for conveying dhamma with a repetitive structure, repeating sentence structure, repeating content. It is all about emphasis. Training concentration or practicing dhamma requires practice and repetition in order to 
yield clear, precise understanding; as in chanting, which needs to be performed repeatedly for scrupulous contemplation, repeating the matter to prevent forgetting, to prevent indiscretion.

From the example in the Sakkapañhā Suttas, it appears that in asking and answering, in the end the inquirer or the person with curiosity may become the one who answers himself, because after investigating through the pucchā-vissajjanā process, he or she can come to the understanding and realize that truth on his own. In a sense the aim is to strengthen the reader or the learner. The reader may come to the understanding of Buddhist teaching along with the character in the story, or may even understand before the character does.

\section{Conclusion}

Through studying and comparing concentration-development with the pucchāvissajjanā process, it is concluded that pucchā-vissajjanā is a technique favorable for concentration-development. The reader studies the theory and practices at the same time. However, the practice of concentration will lead to wisdom and knowledge. Here concentration- development is being inferred to in a broad sense and in a manner which is only the basis of the primary level of dhamma practice, because dhamma practice of concentration-development also involves patterns and details that are very complex. Therefore, here I state only that pucchāvissajjanā is one significant instrument in composing Buddhist literature, and it is an instrument favorable for concentrationdevelopment at the primary level, which constitutes a good beginning for concentration-development at higher levels. The aim of this paper proposes to show the significance of pucchā-vissajjanā, as a technique for teaching employed by the
Buddha and his disciples that is effective in inducing understanding of the Buddhadhamma. Moreover, it is a mnemonic technique for reciting, preserving, and transmitting the Buddhist teachings. Pucchā-vissajjanā is a technique or form that gives unity to the composition, with methodical development of plot, with an orderly and systematic presentation, connecting each problem together neatly and ingeniously in order to convey Buddhist concepts or teachings. The literary value of pucchā-vissajjanā is basically an attribute of language form, the beauty and purpose of which is the induce wisdom. Therefore, it can be a powerful stimulus for thinking and faith. Furthermore, pucchā-vissajjanā is also significant as a technique favorable for concentration-development, because the process of communicating dhamma through pucchā-vissajjanā is in congruence and parallel with the process of training concentration. Pucchā-vissajjanā is not only the setting of issues or a general method of communication. Its importance also lies in harmonious parallel with the pattern of dhamma practice, for it can help one attain concentration and knowledge and understanding of the Buddhadhamma. Thus studying the relation between the form and content of Buddhist literature is highly recommended, as investigation of the manner in which the substance of Buddhism and the method by which it is conveyed constitute a harmonious whole. Such a study would be beneficial to education, both in the scope of literature and of Buddhist studies. 


\section{References}

Allon, Mark. 1997. Style and Function: A Study of the Dominant Stylistic Features of the Prose Portions of Pāli Canonical Sutta Texts and their Mnemonic Function. Tokyo: The International Institute for Buddhist Studies.

Allon, Mark. 1997. 'The Oral Composition and Transmission of Early Buddhist Texts' in Indian Insights: Buddhism, Brahmanism and Bhakt. Peter Connolly and Sue Hamilton (eds.), London: Luzac Oriental.

Basu, Rabindra Nath. 1978. A Critical Study of the Milindapañha. Calcutta: Firma KLM Private Limited.

Cousins, L.S. 1983. Pāli Oral Literature in Buddhist Studies: Ancient and Modern. Phillip Denwood and Alexander Piatigorsky (eds.). London: Curzon.

Davids, Rhys and William Stede (eds.). 1998. The Pāli Text Society's PāliEnglish Dictionary. Oxford: The Pali Text Society.

Dhammapitaka, Pra. 2543. Dictionary of Buddhism. Bangkok: Mahachulalongkornrajavidayalaya University.
Gethin, Rupert. 1992. The Mātikās: Memorization, Mindfulness, and the List, in The Mirror of Memory: Reflection on Mindfulness and Remembrance in Indian and Tibetan Buddhism. Janet Gyatso (ed.), Albany: State University of New York Press.

Gombrich, Richard. 1994. How Buddhism Began. Malaysia: Synergy Books International.

Griffiths, Paul. Concentration or Insight: the Problematic of Theravāda Buddhist Meditation-Theory in The Journal of the American Academy of Religion. XLIX/4.

Hare, E.M. (trans.). 1973. The Book of the Gradual Saying. Vol. III, London: The Pali Text Society.

Horner, I.B (trans.). 1952. The Book of the Discipline, Vol. II. London: The Pali Text Society.

Horner, I.B. (trans.). 1975. The Collection of the Middle Length Sayings (Majjhima Nikāya), Vol.II. London: Pali Text Society.

Horner, I.B. (trans.). 1976. The Collection of the Middle Length Sayings (Majjhima Nikāya), Vol.III. London: Pali Text Society.

Lopez, Donald S. 2001. The Story of Buddhism: A Concise Guide to its History and Teachings. New York: HarperCollins. 
Nānamoli, Bhikkhu (trans.). 1975. Visuddhimagga (The Path of Purification). Kandy Sri Lanka: Buddhist Publication Society.

Norman, K.R. 1989. The Pāli Language and Scriptures, in The Buddhist Heritage. Tadeusz Skorupski (ed.). U.K.: The Institution of Buddhist Studies.

Oldenberg, Hermann. 1991. The Doctrine of the Upanisads and Early Buddhis. Delhi: Motilal Banarsidass.

Rhys Davids, T.W. and C.A.F. (trans.). 1971. Dialogues of the Buddha. London: The Pali Text Society.

'Sanghītiyavamsa', in Wannakam Samai ratanakosin Vol. 3, 1996, Bangkok: Krom Silpakorn.

Sloane, Thomas O. 2001. Encyclopedia of Rhetoric. Oxford: Oxford University Press.

Walshe, Maurice (trans.). 1987. Thus Have I Heard: The Long Discourses of the Buddha (Digha Nikāya). London: Wisdom Publications.

Warder, A.K. 1970. Indian Buddhism. Delhi: Motilal Banarsidass.

Woodward, F.L. (trans.). 1982. The Book of the Gradual Sayings, Vol. II. London: The Pāli Text Society. 